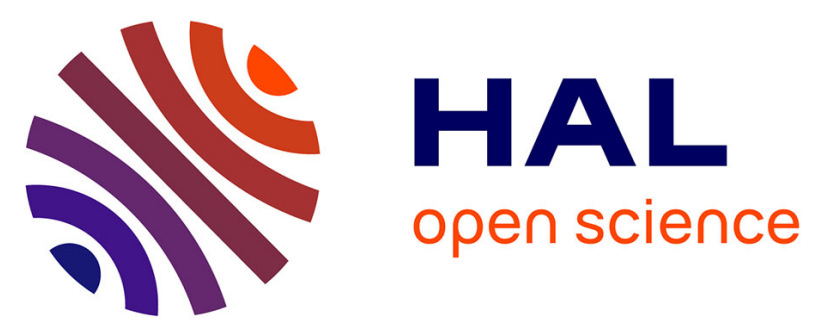

\title{
Modelling the stomatal resistance under water comfort and restriction to assess the transpiration of a greenhouse New Guinea impatiens crop
}

Hacene Bouhoun Ali, Etienne E. Chantoiseau, Pierre-Emmanuel Bournet, Patrice Cannavo, Christophe C Migeon, Mathilde Sourgnes

\section{To cite this version:}

Hacene Bouhoun Ali, Etienne E. Chantoiseau, Pierre-Emmanuel Bournet, Patrice Cannavo, Christophe C Migeon, et al.. Modelling the stomatal resistance under water comfort and restriction to assess the transpiration of a greenhouse New Guinea impatiens crop. Acta Horticulturae, 2017, 1170, pp.611 - 618. 10.17660/ActaHortic.2017.1170.76 . hal-01705933

\section{HAL Id: hal-01705933}

\section{https://institut-agro-rennes-angers.hal.science/hal-01705933}

Submitted on 7 Jul 2019

HAL is a multi-disciplinary open access archive for the deposit and dissemination of scientific research documents, whether they are published or not. The documents may come from teaching and research institutions in France or abroad, or from public or private research centers.
L'archive ouverte pluridisciplinaire HAL, est destinée au dépôt et à la diffusion de documents scientifiques de niveau recherche, publiés ou non, émanant des établissements d'enseignement et de recherche français ou étrangers, des laboratoires publics ou privés. 


\title{
Modelling the Stomatal Resistance Under Water Comfort and Restriction to Assess the Transpiration of a Greenhouse New Guinea Impatiens Crop
}

\author{
H. Bouhoun Ali, E. Chantoiseau, P.E. Bournet, P. Cannavo, C. Migeon and M. Sourgnes \\ Agrocampus Ouest, UP EPHor Environmental Physics and Horticulture Research Unit, \\ F-49045 Angers,
}

France.

Keywords: soil-plant-atmosphere, pots, peat, matric potential, porometer, Penman Monteith, direct method

\begin{abstract}
In greenhouses, reducing water consumption by increasing water efficiency is of high interest. To reach this goal, predictive models of soil-plant-atmosphere water transfers may be used. Such models are however presently mainly developed for open field conditions and very few models exist for greenhouse plants grown in pots. Implementing these models requires an accurate estimate of the stomatal resistance $\mathbf{R}_{\mathrm{s}}$. The aim of this work is to implement and adapt the multiplicative Jarvis model (1976) to calculate $R_{s}$ for greenhouse potted plants not only under water comfort but also under water restriction, through the introduction of a new multiplicative function depending on the growing media matric potential. The obtained model could then be tested to evaluate transpiration. To establish the model parameters, an experiment was conducted during sixteen weeks inside a greenhouse with ornamental plants grown in containers on shelves. Both water comfort and water restriction conditions were applied. The peat matric potential, radiation, temperature and humidity were continuously recorded while $\mathbf{R}_{\mathrm{s}}$ was measured and transpiration was assessed with scales. Data collected on four weeks were used to fit the parameters of $\mathbf{R}_{\mathrm{s}}$ depending on radiation and water pressure deficit under water comfort. The multiplicative matric potential function was then deduced from $\mathbf{R}_{\mathrm{s}}$ measured on stressed plants. The model was validated against data and showed its ability to assess $R_{s}$ both under comfort and restriction conditions. The developed model of $R_{s}$ could therefore help assess transpiration under various irrigation regimes.
\end{abstract}

\section{INTRODUCTION}

At a time when ecological concerns are growing, a better management of water resources in the horticultural sector appears to be necessary to remain competitive. The control of irrigation requires an understanding of transpiration processes to adjust the amount of water available to plants to their transpiration. In this context, the development of models to predict water transfers in the soil-plant-atmosphere continuum could help optimize water inputs.

Generally speaking, the estimation of transpiration is based on a representative model of the stomata behavior according to the climatic parameters (solar radiation, air temperature, vapor pressure deficit) and to the water availability in the substrate (Monteith, 1973; Gerosa et al., 2012). Stomata opening and closing can be assessed through the evolution of the stomatal resistance $\left(\mathrm{R}_{\mathrm{s}}\right)$. According to Kaufmann (1982), in 
the case of water comfort the major determinants of $R_{s}$ are radiation, and vapor pressure deficit, while for water restriction cases the availability of water inside the soil intervenes in addition to these determinants. Modeling $\mathrm{R}_{\mathrm{s}}$ for open field conditions was extensively undertaken over the past 50 years with the help of new sensors that made it possible the direct measurement of $\mathrm{R}_{\mathrm{s}}$, such as porometers and gas exchange analyzers (Damour et al., 2010). Almost all models for open field were deduced from two seminal works by Jarvis (1976) and Ball et al. (1987) but very few models exist for plant cultivated in container under greenhouse conditions (Casaroli et al., 2010). Moreover, most models found for $\mathrm{R}_{\mathrm{s}}$ under such conditions focused on the soil-plant system, or the plant-atmosphere system and very few take into account real coupling between the three compartments. For those, adaptation to water restriction conditions was achieved by adding a function expressing the water status of the soil or plant as performed by Gang et al. (2012).

The aim of this work is to develop a model able to estimate $R_{s}$ and then use this model to assess the transpiration. First, $R_{\mathrm{s}}$ was modeled under water comfort conditions using the multiplicative model of Jarvis for potted Impatiens. It was then adapted to water restriction conditions by adding a multiplicative function based on the matric potential of the substrate. Finally, the complete $\mathrm{R}_{\mathrm{s}}$ models (for water comfort and restriction) were used in the Penman Monteith (PM) and Direct Method (DM) to estimate transpiration under comfort and water restriction conditions. Although PM model is the reference method to estimate evapotranspiration, the simpler DM (Morille et al., 2012) was also tested to assess its efficiency.

\section{MATERIALS AND METHODS}

\section{Experimental setup}

Experiments were conducted inside a $100 \mathrm{~m}^{2}$ glasshouse compartment located in Angers $\left(47^{\circ} 28^{\prime} \mathrm{N}, 0^{\circ} 33^{\prime} \mathrm{E}\right)$ in north-western France. Experiments were carried out during 16 weeks from $26^{\text {th }}$ March to $20^{\text {th }}$ July 2014 with Impatiens (Novae-guinea, cv.'Sonic Scarlet') as plant model. Young Impatiens plants were potted in $0.74 \mathrm{~L}$ containers $(8.7 \mathrm{~cm}$ height $)$ filled in with fine peat with homogeneous peat bulk density (i.e. $0.12 \mathrm{~g} \mathrm{~cm}^{-3}$ ). Plants were equally distributed on four shelves with an initial density of 28 plants per $\mathrm{m}^{2}\left(18 \mathrm{~m}^{2}\right.$ total area). During the experiment, the plant density was decreased to favor plant growth, but insuring that plants covered entirely the shelves (final density of 15 plants per $\mathrm{m}^{2}$ ). Plants were irrigated by periodically flooding with a nutrient solution, and flowers were regularly removed. For the purpose of the study irrigation was periodically stopped on one shelf until plants evidenced water stress visual signs. For the plants on the three other shelves, water-comfort conditions were applied with water potential in peat kept higher than $-2 \mathrm{kPa}$. In order to avoid excessive temperatures, a shading screen was used and the roof vents were fully open as soon as external temperatures exceeded $20^{\circ} \mathrm{C}$.

\section{Experimental measurements}

Water-comfort and water-restricted crop transpirations were measured by two scales (Melter-Toledo, Greifensee, Switzerland, $\pm 0.1 \mathrm{~g}$ ) located approximately at the center of the shelves (Fig. 1) and carrying several containers. The above canopy global radiation was measured by a radiometer (CNR1, Kipp \& Zonen, Delft, The Netherlands, $\pm 10 \%$ ). The air temperature ( $\mathrm{Ta}, \pm 0.1 \circ \mathrm{C}$ ) and relative humidity (RHa, $\pm 2 \% \mathrm{HR}$ ) above the canopy were measured by shielded and ventilated sensors (Vaisala HMP45C, Campbell Scientific Ltd., Antony, France). The leaf temperatures were measured by 
thermocouples at two levels. Peat matric potential $(\Psi, \mathrm{kPa})$ was measured at the middle height of ten containers with tensiometers (SDEC 1300, France). Among them, four were placed in the water-comfort shelf and the six others in the water-restricted shelf. All measurements were performed every 3 seconds, averaged over 10 minute periods and recorded by a data logger system (CR5000, Campbell Scientific Ltd., Antony, France).

Stomatal resistances were measured on leaves of the upper part of the canopy (or sunlit leaves) as well as on leaves of the bottom part (or shaded leaves) with a porometer (AP4, Delta-T Device, United Kingdom). The accuracy of this instrument is $\pm 20 \mathrm{~s} \mathrm{~m}^{-1}$

for $R_{s}$ in the range [20-40 s m$~^{-1}$ ] and $\pm 10 \%$ for $R_{s}$ in the range [50-4000s m $\mathrm{s}^{-1}$ ]. Five measurements were done for each sunlit and shaded leaves of different plants for each water condition. The measurements of $\mathrm{R}_{\mathrm{s}}$ were replicated every half an hour from 8:00 am to $8: 00 \mathrm{pm}$ for weeks $10,12,14,16$ and from 5:30 am to 23:00 pm for week 11 after plantation

\section{MODELLING METHODOLOGY}

\section{Stomatal resistance} (Eq. 1):

According to Jarvis (1976), $\mathrm{R}_{\mathrm{s}}$ can be expressed using a multiplicative model

$$
R_{s}=R_{s, \min } \cdot f_{1}\left(R_{g}\right) \cdot f_{2}\left(V P D_{a}\right) \cdot f_{3}(\Psi)
$$

where $R_{s, \min }$ is the minimal measured stomatal resistance, $R g\left(\mathrm{~W} \mathrm{~m}^{-2}\right)$ is the global radiation measured above the canopy, $\Psi(\mathrm{kPa})$, the substrate water potential and, $V P D_{a}$ $(\mathrm{Pa})$, the vapor pressure deficit. $V P D_{a}$ is deduced from measurements of humidity and temperature above the canopy. The influence of these different factors may be quantified through the identification of three functions $f_{1}\left(R_{g}\right), f_{2}\left(V P D_{a}\right)$ and $f_{3}(\Psi)$.

For function $f_{1}$ Baille, (1994a) recommended the use of Eq. 2, while Boulard et al. (1991) recommended Eq. 3 for $f_{2}$, and Nikolov et al. (1995) Eq. 4 for $f_{3}$ :

$$
\begin{gathered}
f_{1}(R g)=\frac{a_{1}+R_{g}}{b_{1}+R_{g}} \\
f_{2}(V P D)=1+\mathrm{a}_{2} \exp \left(\mathrm{b}_{2}\left(V P D-V P D_{0}\right)\right) \\
f_{3}(\Psi)=1+\left(\frac{\Psi}{\Psi_{1}}\right)^{a_{3}}
\end{gathered}
$$

where $V P D_{0}$ is the vapor pressure deficit for which $\mathrm{R}_{\mathrm{s}}$ is minimal. $\Psi_{1}$ is the water potential for which $R_{s}$ under water restriction is twice the stomatal resistance under water comfort. $a_{i}$ and $b_{i}$ and $\Psi_{1}$ are parameters to be determined, using linear regressions for instance.

\section{Transpiration}

The models usually implemented to estimate transpiration in the case of hypostomatic plants are the Penman-Monteith (PM) and the so-called Direct Method (DM). The PM has been widely used and proved its accuracy for both hydric water comfort and restriction conditions (Caspari et al. 1993). The DM was also tested as it is easier than PM to implement because of its lower number of parameters. One of its drawbacks however, is that it requires the knowledge of the leaf temperature.

1. Direct Method model. According to the DM approach, the transpiration may be expressed as a function of the leaf-to-air vapor pressure deficit (Eq.5)

$$
E=\frac{\rho_{a} \cdot L A I \cdot C_{p a}}{\gamma} \frac{P_{v s a t, l}-P_{v, a}}{r_{a}+r_{c}}
$$


where $E$ is the canopy transpiration rate $\left(\mathrm{W} \mathrm{m}^{-2}\right), \rho_{a}$ is the air density $\left(\mathrm{kg} \mathrm{m}^{-3}\right), C_{p a}$ is the specific heat of air $\left(\mathrm{J} \mathrm{kg}^{-1} \mathrm{~K}^{-1}\right), \gamma$ is the psychrometric constant. $r_{a}$ and $r_{c}$ are the leaf aerodynamic resistance and the canopy stomatal resistances $\left(\mathrm{s} \mathrm{m}^{-1}\right)$, respectively. LAI is the Leaf Area Index $\left(\mathrm{m}^{2} \mathrm{~m}^{-2}\right), P_{\text {vsat }-l}$ is the vapor pressure of the air at saturation in the stomata chamber $(\mathrm{Pa})$ and $P_{v-a}$ is the water vapor pressure of the air $(\mathrm{Pa})$.

2. Penman-Monteith model. The Penman-Monteith model is derived from the combination of the energy balance equation and the latent/sensible heat flux expressions (Eq. 6):

$$
\mathrm{E}=\frac{\Delta R_{n}+2 \rho_{a} L A I C_{p a} V P D_{a} / r_{a}}{\Delta+2 \gamma\left(1+\frac{r_{c}}{r_{a}}\right)}
$$

where $R_{n}$ is the net radiation flux absorbed by the crop $\left(\mathrm{W} \mathrm{m}^{-2}\right)$. It is systematically assumed to be equal to the net radiation measured above the crop, thus neglecting the radiation exchanges below the canopy and to the ground. $V P D_{a}$ is the vapor pressure deficit $(\mathrm{Pa})$ and $\Delta$ is the slope of the saturated water vapor pressure curve according to temperature.

\section{RESULTS AND DISCUSSION}

\section{Fit of $\mathbf{R}_{\mathrm{s}}$ models}

The parameters of functions $f_{1}$ and $f_{2}$, (Eq. 2-5) were fitted on the values recorded on the $10^{\text {th }}, 11^{\text {th }}, 14^{\text {th }}$ and $16^{\text {th }}$ weeks of experiments after transplanting for wellirrigated plants. Once the model was established under water comfort, it was adapted to water restriction cases by fitting the parameters of function $f_{3}$ (Eq. 5) on measurements of weeks 10, 11, 14 and 16 undertaken for water restricted plants. The general model of $R_{s}$ obtained under both hydric conditions is given by Eq. 7 .

$$
R_{S}=42\left(\frac{R_{g}+148.9}{R_{g}+11.71}\right)(1+0.47 \exp (0.64(V P D-1.84)))\left(1+\left(\frac{\Psi}{-11.41}\right)^{1.05}\right)
$$

From results concerning $f_{3}$ (Fig. 2) it can be seen that the agreement between calculated and measured values is quite low with $r^{2}=0.47$. It should be noted that most of the error is due to the large values of the stomatal resistance ratio (mainly recorded at night) and the $f_{3}$ curve. Indeed, $\mathbf{R}_{\mathrm{s}}$ depends not on the soil water potential but on the leaf water potential (Jarvis, 1976). In the present case, the soil water potential was used because technically it was easier to assess than the leaf water potential. In general, both potentials vary in the same manner all day long, but during summer days the plants cannot absorb water from the substrate fast enough to balance their transpiration. The leaf water potential thus decreases rapidly and the proportionality with soil potential is lost (Tuzet et al., 2003). Such conditions lead to a closure of the stomata that is not taken into account by the present model (Eq. 7).

The $\mathrm{R}_{\mathrm{s}}$ model was validated against data collected for week 12 under comfort (Fig. 3A) and water restriction (Fig. 3B). It was applied for the sunlit leaves and showed its ability to simulate $R_{s}$ under water comfort conditions with $r^{2}=0.74$ and $\mathrm{RMSE}=419 \mathrm{~s} \mathrm{~m}^{-1}$. During most of the day, the agreement between measured and calculated data was quite good, but the model failed to depict the sharp increase of $R_{s}$ in the evening. This increase was due to the closure of the stomata when the unbalance between water transpiration and absorption led to a decrease of the leaf water potential. As $R_{s}$ was used to estimate the transpiration, which in such conditions was limited, the 
developed model of $R_{S}$ can be considered as satisfactory (i.e. the model of $R_{s}$ has some limits to calculate high $R_{s}$ values; but for such values, the transpiration is negligible).

On the first two days after the end of irrigation, measured stomatal resistances for water restriction (displayed on Figure 3B) are of the same order of those under comfort conditions. From the third day, water restriction starts to cause an increase of $R_{s}$. The agreement between the measured and the calculated $R_{s}$ is very good with $r^{2}=0.86$ and $\mathrm{RMSE}=192 \mathrm{~s} \mathrm{~m}^{-1}$. Introducing a supplementary multiplicative function of the substrate water potential makes it possible to predict the increase of $R_{s}$ along the investigated week. Incidentally, the stomata closure in the evening is better represented by using a substrate water restriction function.

\section{Transpirations models}

The modeled $\mathrm{R}_{\mathrm{s}}$ were then used to estimate the plants transpiration using the direct model (DM) and the Penman-Monteith (PM) model. Again, both comfort and water restriction cases were investigated.

Both models of transpiration require the estimation of $r_{a}$ and $r_{c}$. In the present study $r_{a}$ was considered constant (Baille et al., 1994b): $r_{a}=271 \mathrm{~s} \mathrm{~m}^{-1} . r_{c}$ was calculated by taking the average of parallel sum of the individual $R_{S}$ of shaded and sunlit leaves (Caspari et al., 1993). The measurements of $R_{s}$ indicated that the value of $R_{s}$ for shaded leaves was more than twice (2.37) that of sunlit leaves for both water comfort and restriction, as confirmed by Caspari et al. (1993). As the canopy was dense $\left(\mathrm{LAI}=2.36 \mathrm{~m}^{2} \mathrm{~m}^{-2}\right.$ for a plant height of $\left.24 \mathrm{~cm}\right)$, the part of sunlit leaves in $\mathrm{r}_{\mathrm{c}}$ was negligible, hence we assumed that $r_{c}=\mathrm{R}_{\mathrm{s}}$ (shaded leaves).

The results of measured and calculated transpiration for comfort and water restriction conditions are presented on Figures 4 (comfort) and 5 (water restriction). As predicted, the transpiration under water restriction was lower than the one under comfort. The transpiration predicted for water comfort with both PM and DM models were in good agreement with measured transpiration with $\mathrm{r}^{2}=0.88$ for $\mathrm{PM}$ and $\mathrm{r}^{2}=0.84$ for DM. As expected from the $\mathrm{R}_{\mathrm{s}}$ modeling that did not take into account the leaf water dynamics during the day, the transpiration was underestimated by both models in the morning, and overestimated in the afternoon. Overall, the agreement between both models was good, with PM model being slightly better, as stated by the higher $\mathrm{r}^{2}$. The relative error for accumulated transpiration was also estimated, leading to a $17.66 \%$ error for PM, and $28 \%$ for DM. Under water restriction, the agreement between measured values and both models was slightly lower with $\mathrm{r}^{2}$ equal 0.72 for PM model and 0.69 for DM. However, these results evidenced good results of the investigated models. In this case, the relative error for cumulated transpiration was $6.27 \%$ for DM, and only $2.74 \%$ using PM.

\section{CONCLUSIONS}

In this study the stomatal resistance was modeled with the Jarvis method both for comfort and water restriction conditions. In the second case, a multiplicative function describing the stomatal closure according to the soil water potential was developed. Model parameters were estimated from $R_{s}$ measurement during four weeks. The validation against data recorded during a fifth week showed good agreement.

The good results of predicted transpiration for both hydric conditions confirm that the model established for $R_{s}$ is relevant to depict the evolution of $R_{s}$ under water restricted conditions. Moreover, results show that the direct model could be used to calculate 
transpiration for both hydric conditions.. As it is easier to apply with less mandatory input, it is a good candidate for transpiration forecasting for greenhouse crop.

Nevertheless, the accuracy of $R_{S}$ model can still be increased in order to get better prediction of the temporal evolution of $R_{S}$ by including leaf water potential. This improvement of $R_{s}$ model would help get more accuracy for the hourly dynamics prediction of transpiration, and would be a powerful tool for precision horticulture.

\section{Literature cited}

Baille, M., Baille, A. and Laury, J.C. 1994a. Simplified model for predicting evapotranspiration rate of 9 ornamental species vs climate factor and leaf area. Sci.Hortic. Amsterdam 59:217-232.

Baille, M., Baille, A., Laury, J.C. 1994b. Canopy surface resistances to water vapour for nine greenhouse pot plant crops. Sci.Hortic. France 57:143-155.

Ball, M.C, Woodrow, I.E. and Berry J.A. 1987. A model predicting stomatal conductance and its contribution to the control of photosynthesis under different environmental conditions. In Progress in Photosynthesis Research, Ed I. Biggins. Martinus Nijhoff Publishers. Netherlands. p.221-224.

Bartzanas, T., Boulard, T. and Kittas, C. 2004. Effect of vent arrangement on windward ventilation of a tunnel greenhouse. Biosystems Engineering 88:479-490.

Boulard, T., Baille, A., Mermier, M. and Villette, F. 1991. Measurement of stomatal resistance and transpiration in a greenhouse tomato canopy - Comparison between a 1 layer and a multilayer model. Agronomie 11:259-274.

Caspari, H.W., Green S.R. and Edwards, W.R.N. 1993. Transpiration of well-watered and water-stressed Asian pear trees as determined by lysimetry, heat-pulse, and estimated by a Penman-Monteith model. Agricultural and Forest Meteorology 67:13-27.

Damour, G., Simonneau, T., Cochard, H. and Urban, L. 2010. An overview of models of stomatal conductance at the leaf level. Plant Cell Environ 33:1419-1438.

Gang, L., Lu L, Yongyi, D., Dongsheng, A., Yongxiu, L., Weihong, L., Xinyou, Y., Wenwen, L., Jingqing, S., Yanbao, Z., Jianfeng, D., Weiping, C. and Chunjiang, Z. 2012. Testing two models for the estimation of leaf stomatal conductance in four greenhouse crops cucumber, chrysanthemum, tulip and lilium. Agricultural and Forest Meteorology 165:92-103.

Jarvis, P.G. 1976. The interpretation of the variations in leaf water potential and stomatal conductance found in canopies in the field. Philosophical Transactions of the Royal Society of London. Serie B 273:593-610.

Kaufmann, M.R. 1982. Leaf conductance as a function of photosynthetic photon flux density and absolute humidity difference from leaf to air. Plant Physiol 69:1018-1022.

Monteith, J.L. 1973. Principles of environmental physics. Edward Arnold, London. p.241.

Morille, B., Migeon, C. and Bournet, PE. 2012. Is the Penman-Monteith model adapted to predict crop transpiration under greenhouse conditions? Application to a New Guinea Impatiens crop. Scientia Horticulturae 152:80-91.

Nikolov, N.T., Massman, W.J., and Schoettle, A.W. 1995. Coupling biochemical and biophysical processes at the leaf level: an equilibrium photosynthesis model for leaves of C3 plants. Ecol. Model. 80:205-235.

Tuzet, A., Perrier, A. and Leuning, R. 2003. A coupled model of stomatal conductance, photosynthesis and transpiration. Plant Cell and Environment 26:1097-1116. 


\section{$\underline{\text { Figures }}$}

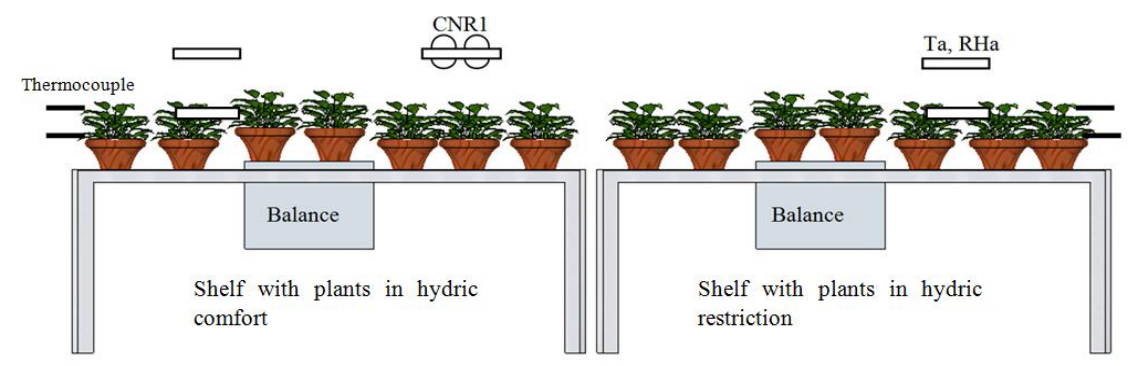

Fig. 1. Experimental device.

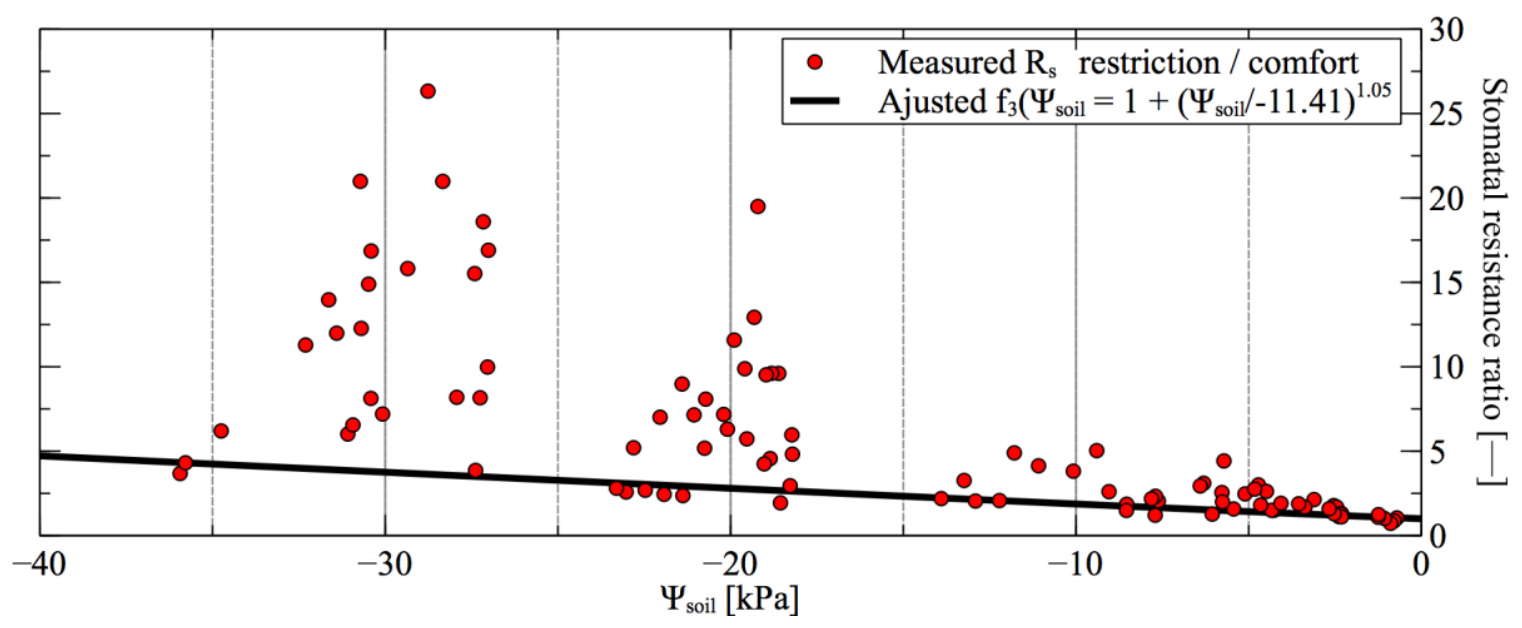

Fig. 2. Fitted function of stress $f_{3}(\Psi)$.
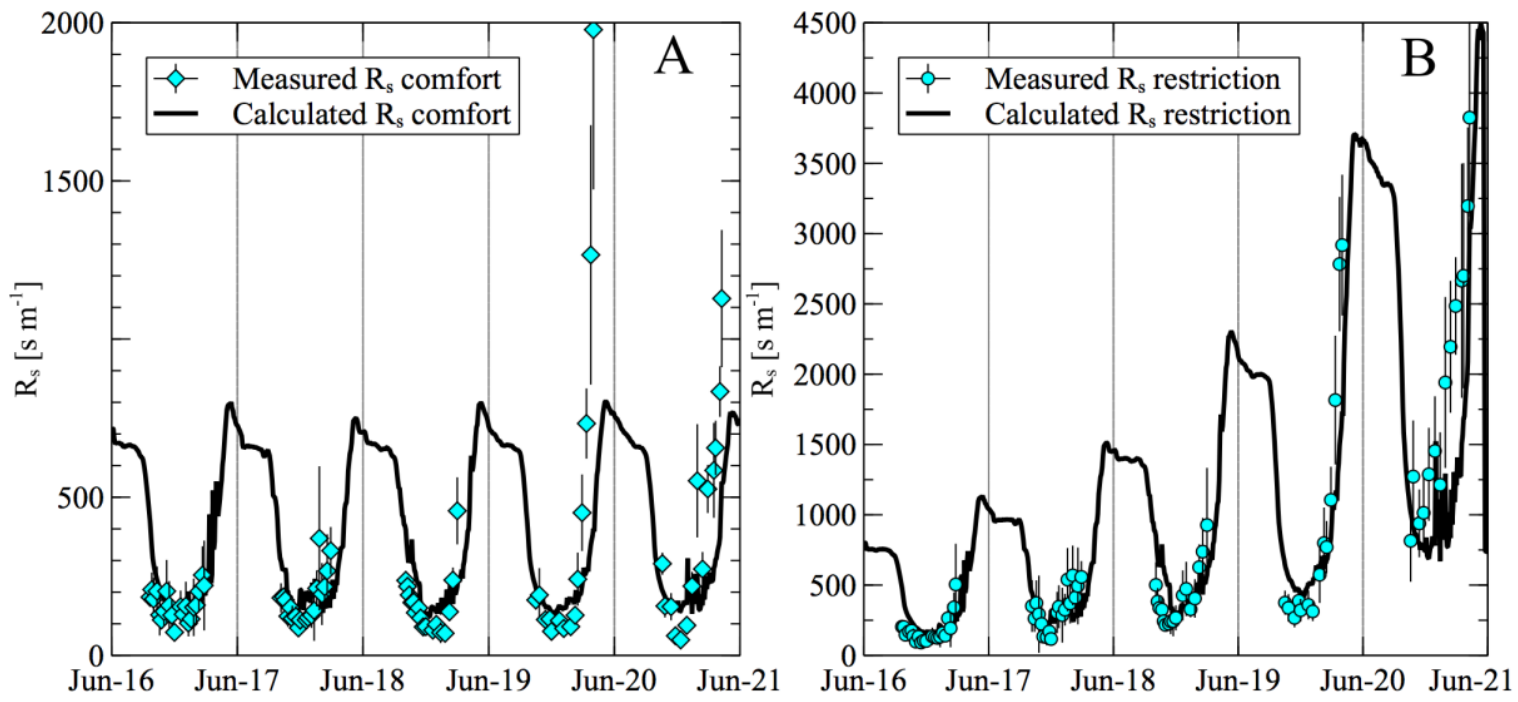

Fig. 3. Measured and calculated $\mathrm{R}_{\mathrm{s}}$ for plants under comfort (A) and water restriction (B) conditions 12 weeks after plantation. 


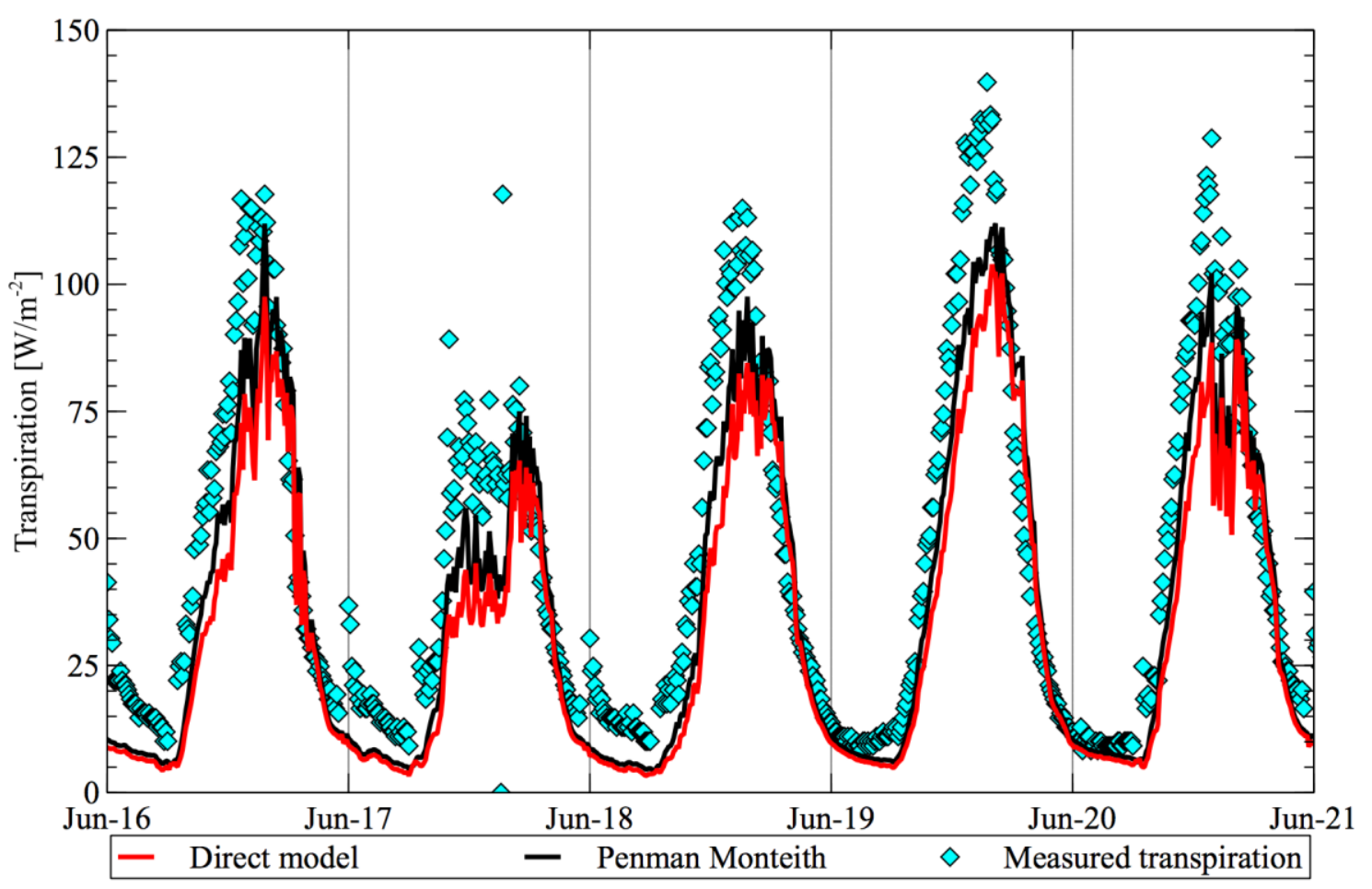

Fig. 4. Measured and calculated transpiration for plants under water comfort conditions 12 weeks after plantation.

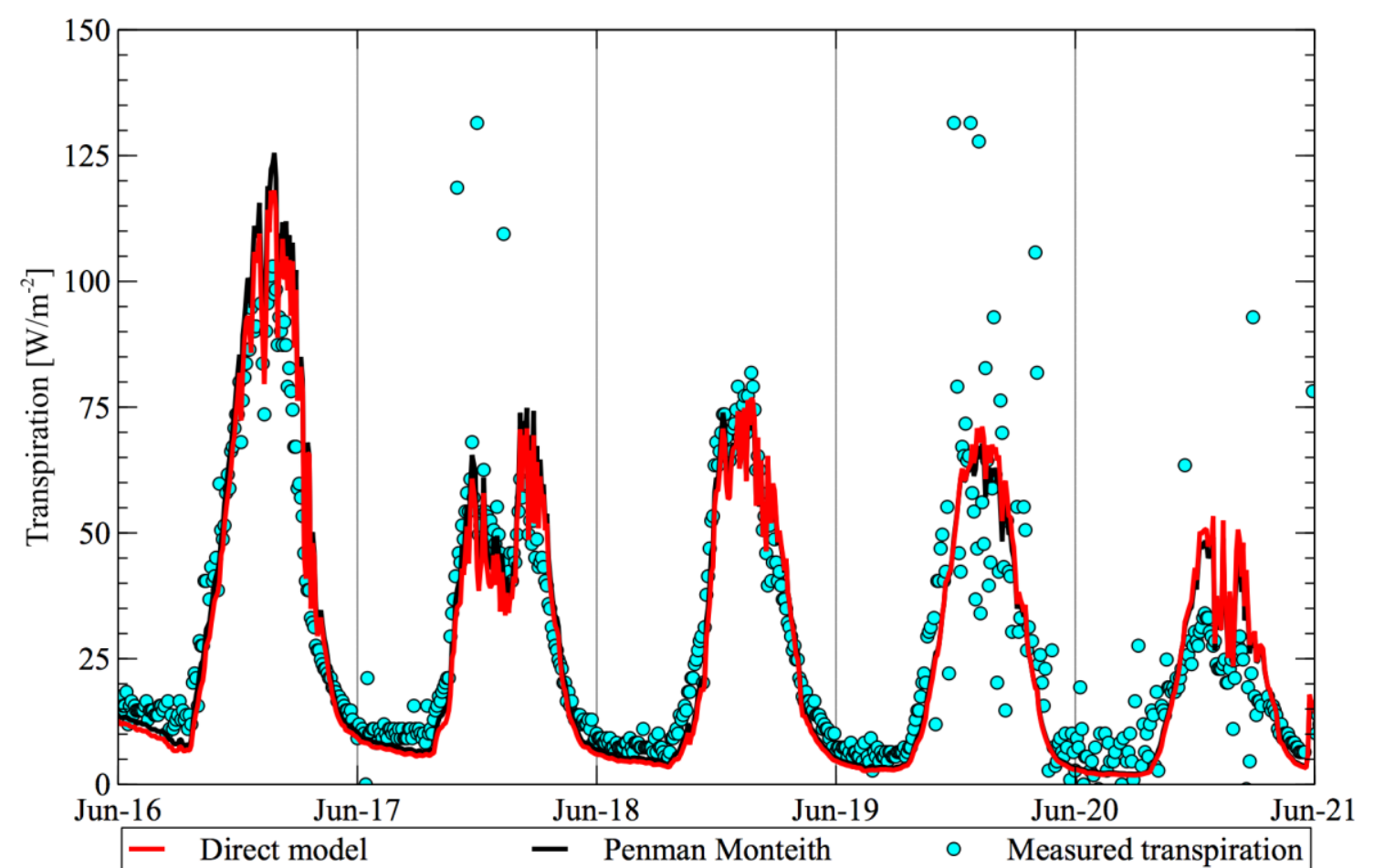

Fig. 5. Measured and calculated transpiration for plants under water restriction conditions 12 weeks after plantation. 